\title{
G. H. MEAD IN THE HISTORY OF SOCIOLOGICAL IDEAS
}

\author{
FILIPE CARREIRA DA SILVA
}

\begin{abstract}
My aim is to discuss the history of the reception of George Herbert Mead's ideas in sociology. After discussing the methodological debate between presentism and historicism, I address the interpretations of those responsible for Mead's inclusion in the sociological canon: Herbert Blumer, Jürgen Habermas, and Hans Joas. In the concluding section, I assess these reconstructions of Mead's thought and suggest an alternative more consistent with my initial methodological remarks. In particular, I advocate a reconstruction of Mead's ideas that apprehends simultaneously its evolution over time and its thematic breadth. Such a historically minded reconstruction can be not only a useful corrective to possible anachronisms incurred by contemporary social theorists, but also a fruitful resource for their theory-building endeavors. Only then can meaningful and enriching dialogue with Mead begin. (C) 2006 Wiley Periodicals, Inc.
\end{abstract}

\section{SOCIOLOGY AND THE History OF IDEAS}

This article argues that George Herbert Mead (1863-1931) should be treated as a sociological classic. This assertion, however, requires justification. In effect, beyond the sociohistorical nature of the canon-formation process (which is dealt with later in the article), a justification of the above assertion has to take into consideration three different dimensions, which can be formulated as three correlated questions. Hence, if one wishes to study Mead as a classic, one has to ask: "What is a classic?" "What are the functions that a classic fulfills?" and "How should such writings be analyzed?"

A number of possible answers can be given to the first question. The essential point seems to be covered by Jeffrey Alexander's proposal that classics should be seen as earlier works of human exploration that are given a privileged status in the light of contemporary explorations of the same kind (Alexander, 1987/1993). In other words, this privileged status refers to the capacity of classic texts to generate a myriad of critical arguments about themselves, as well as to their ability to shake off such arguments (Calvino, quoted in Poggi, 1996, p. 46). Thus, a classic is a text written by someone in the past that still holds the ability to provoke controversies among current practitioners of the discipline. A classic text or author continues to be regarded as an exemplary mode of dealing with a certain kind of problem, and can thus be used as an intellectual tool for present purposes.

To answer the second question, the idea that a classic constitutes a symbolic figure reducing the complexity (the number of possibilities for action) ${ }^{1}$ inherent to scientific activity best explains why social scientists, instead of discussing specific elements of some author's

1. See Luhmann (1979). However, it must be said that a similar idea had already been suggested two decades before by Alvin Gouldner, in his introduction to Durkheim's Socialism. Gouldner, discussing the functions performed by sociological myths, suggested that "A founding father is a professional symbol" (Gouldner, quoted in Jones, 1977, p. 292). A similar argument was put forth by Alexander (1982).

FILIPE CARREIRA DA SILVA is an assistant researcher at the University of Coimbra, Portugal, and a junior research fellow at Wolfson College, Cambridge, UK. In 2003/2004, he was a Fulbright visiting scholar at the University of Harvard and the University of Chicago. He is the author of Habermas and the Public Sphere (Lisbon, 2002), Virtue and Democracy: A Study in Republican Ideas (Lisbon, 2004), and G. H. Mead: A Critical Introduction (Polity Press, forthcoming). 
theory, usually refer to the name of that author as encapsulating all of his or her writings. Thus, complexity is reduced by speaking of, say, a "Parsons" or a "Mead." Moreover, these symbolic figures influence what qualifies as a sociological theory, which professional jargon sociologists are to speak in, and which problems may be the object of sociological research (see Connell, 1997, p. 1512). Another relevant symbolic function performed by a classic is related to the creation of "rituals of solidarity" between sociologists (see Stinchcombe, 1982).

The third point is probably the most complex and, accordingly, the one that deserves most attention. Influenced by the so-called "new history of science" that followed the publication of Kuhn's The Structure of Scientific Revolutions (1962), Merton published the first article (Merton, 1967; see also Jones, 1983) in which a sociologist addressed the more historically minded and anti-progressivist approach to the history of science. In that article, the distinction between the history of sociological theories and the systematic substance of those theories was seen as the key to (at least some of) the problems that haunted sociology at the time. The kind of history suggested by Merton resembled that proposed, around the same time, by a young historian of political ideas who was trying to generalize the methodological insights of a number of other scholars - namely, Herbert Butterfield, R. G. Collingwood, Peter Laslett, and John Pocock. This young historian was Quentin Skinner, who in 1969 published the first of a series of methodological articles that, with some others by Dunn and Pocock, ${ }^{2}$ formed the methodological core of a new contextualist perspective for the study of the history of political ideas. In fact, in 1965, George Stocking, inspired by the same new history of science, had already tried to offer a new historical method for the study of behavioral sciences, inspired by, but superior to, the historical approaches of the past (Stocking, 1965). It is interesting to note that this article constitutes the editorial of the first number of this journal, in response to which Merton made the following remark: "Another promising sign is the appearance in 1965 of the Journal of the History of the Behavioral Sciences, the first journal devoted wholly to the history of these sciences" (Merton, 1967, p. 7). In sum, during the 1960s, a resurgence of a more contextualist and historical way of reading the texts of the past modified decisively the landscape of the history of the sciences, natural and human sciences alike. As will be seen, my decision to use the historicist method associated with the work of Skinner and Dunn in the study of the ideas of G. H. Mead is closely linked to this broader historical context.

Of course, a discussion of sociology classics entails a reflection on the very functioning and institutional organization of the discipline. Moreover, the above-mentioned historiographic revolution in the study of science, to borrow Kuhn's phrase, is related to the profound changes undergone by sociology in the last few decades. As Alexander cogently demonstrated (1987/1993), the demise of Parsonian structural functionalism during the 1960s and early 1970s is connected to this new way of conceiving the past of science. Many of Parsons's critics tried to show not only that his interpretation of Weber and Durkheim had been contaminated by his own theoretical interests, but also that the missing authors (Simmel, Marx, and Mead, for instance) were suppressed for the same reasons. Concomitantly, the theoretical alternatives to the Parsonian paradigm that started to appear in the 1960 s based their strategies both on the construction of substitute theoretical models and on the reformulation of sociology's canon of classic authors.

This is, briefly, the context of Herbert Blumer's appropriation of Mead's ideas as a way of providing symbolic interactionism (see Blumer, 1937) with a legitimating symbolic figure:

2. There are, however, discernible differences between Skinner's intentionalist approach (Skinner, 1969, 1970, 1971, 1972, 1988) and Pocock's emphasis on paradigmatic languages (see, e.g., Pocock, 1971). For a comparative study of these two authors, see Boucher (1985). For a description of the genesis of the Cambridge school, see Pocock (1985, pp. 1-35). See also Dunn (1968) and Jones (1981). 
"Mead," as a sociological classic, was born. The history of sociology seems to confirm Rorty's dictum: "Like the history of anything else, history of philosophy is written by the victors" (1984/1998, p. 70). Just as Parsons, in The Structure of Social Action (1937/1968), ${ }^{3}$ chose his ancestors (Marshall, Pareto, Weber, and Durkheim), making them converge on a voluntaristic theory of action, so too symbolic interactionists, ethnomethodologists, conflict theorists, and neo-Marxists reformulated the canon (adding new names, reinterpreting others) according to their own interests. This socially constructed and historically contingent nature of the canon of sociology classics has been considered to be a presentist imposition on the study of the discipline's past. ${ }^{4}$ In my opinion, though, the functions fulfilled by the classics justify their study. This is not to say that the myriad of secondary figures around the "founding fathers" is not important. On the contrary, my contention is that it is.

It is interesting to note that it was a book sharing some resemblance to Parsons's 1937 text that proposed an alternative interpretation and recovery of Mead's social theory in the beginnings of the 1980s. Habermas's The Theory of Communicative Action (1981/1984) proposed a theory of action and rationality following a similar pattern to that of Parsons. Here too a number of classic figures of sociology were taken together in a conversation on a topic suggested by Habermas. In the context of such a rational reconstruction of sociology's past, Mead was invited to discuss with Durkheim the genesis of society from the point of view of the individual. The consequence of this imaginary dialogue was the resurgence in the last two decades of interest in Mead's work beyond the domain of symbolic interactionism.

At around the same time, Hans Joas published what was to be one of the most historically minded of the intellectual biographies of Mead (Joas, 1980/1997). In effect, Joas claims his arguments to be drawn not only from Mead's published writings, but, criticizing the current state of scholarship on Mead, also claims to draw from a number of unpublished articles, unknown both to the general public and to the Meadian scholar. Paired with this concern for historical accuracy, there is another dimension in Joas's work that is of interest for the purpose of this article. Acknowledging that one of the strengths of Parsons's 1937 book was the intention of relating the history of theory to systematic theoretical reflection (thus rejecting Merton's thesis that they should be kept apart), Joas proposes, in The Creativity of Action (1992/1996), to rehistoricize Parsons's conception, not merely for reasons of historiographic accuracy, but in order to elaborate further a sociological action theory. This move toward sociological systematic reflection is again indebted to American pragmatism in general, and to the thought of Mead in particular.

The point I wish to stress by discussing the common origin of the more historicist approaches to the history of sociological and political ideas is that there are compelling reasons to apply a Skinnerian contextualist method to the study of a sociological classic. The critical distance that one might gain from our own beliefs and new and more faithful interpretations of past ideas are but two contributions of such an approach. Furthermore, and building on this very same assumption, a number of scholars have already worked along similar lines. Robert Alun Jones has devoted the last two decades of his career to the study of Durkheim's theory of religion following Skinner's method (see Jones, 1977, 1986, 1997), Charles Camic has studied Parsons's early work, ${ }^{5}$ and Fine and Kleinman (1992), Andrew Feffer (1990, 1993),

3. For a seminal account of the influence of this book, see Camic (1989).

4. Charles Camic rejects the practice of "concentrating upon one, often distinctive, subset of past social theories, those currently regarded as sociological classics," since it prevents us from "understanding the complex empirical process whereby social theories emerge, grow, and change" (Camic, 1981, p. 1142).

5. Camic's historicist account of the early stages of Parsons's career has raised an interesting controversy with neo-functionalists. For this controversy, see Camic $(1992,1996)$, and, for the neo-functionalists' view, Alexander and Sciortino (1996). 
and Gary Alan Cook (1993) proposed analogous perspectives for the study of Mead's ideas. One can thus argue that, in simplified terms, our understanding of the classics has become the subject of a controversy between two major poles, usually designated as "historicist/contextualist" and "presentist/textualist." In a nutshell, a historicist approach to the study of the history of social and political ideas refers to a methodology that seeks to grasp the meaning of a text by reconstructing its original context, whereas a presentist approach tends to favor an interpretation of the classics mainly from the point of view of contemporary questions (see Baehr \& O’Brien, 1994).

Having said this, it must be admitted that the historicist approach is far from consensual in sociology. From Alexander's more general criticisms to the humanist approach to the study of intellectual history (see Alexander, 1987/1993, pp. 46 ff.), to Dean Gerstein's controversy with Jones on Durkheim (Gerstein, 1983; for the reply, see Jones, 1984), and Stephen Turner's critique of the contextualist history of sociological thought (Turner, 1983), there is a vast array of doubts about the adequacy of historicist methodological approaches for the study of a discipline that sees itself as inherently presentist. At least, this is the image that Merton and the more empirically oriented sociologists tend to suggest. According to this point of view, sociology occupies a position somewhere between the natural sciences and the humanities: despite regularly resorting to the works of the classics as the latter, there is an empirical orientation that resembles the former.

One means of relating this empirical-oriented self-image of sociology to the historicism vs. presentism dichotomy is Merton's influential distinction between the history and systematics of sociological theory. Merton's positivist conception of sociology, with an internal division of labor analogous to that within the natural sciences (where presumably contemporary theoretical workings were totally independent from historical studies), suggests that a study such as that under discussion in this article can only expect to achieve, at the most, historically relevant conclusions to questions such as "how did Mead's ideas evolve in the light of the intellectual context of his time?" or "what was the filiation of Mead's ideas?" (see Merton, $1949 / 1967$, p. 2). As a matter of fact, Merton, following his own methodological thesis, actually wrote a paper on the oral nature of scientific publication, focusing on, among others, the case of Mead (see Merton, 1980). Nevertheless, a motive for discussing Mead's canonization as a sociological classic is to demonstrate the inadequacy of such a distinction between the historical and systematic dimensions of sociological theories.

In fact, the very historical process of the institutionalization of sociology as a scientific discipline seems to support my thesis. According to the conventional self-image of the history of sociology, there is a foundational moment associated with the radical socioeconomic transformation of western European societies in the course of the nineteenth century, a set of classic texts that analyzes these events in an exemplary and inspiring way for following generations, and a line of direct descent linking the classics to present-day sociologists. In contrast to such a canonical and self-legitimizing conception, R. W. Connell suggests a rather different perspective of sociology's past.

Connell adopts a historicist methodological orientation and focuses his analysis on the case of the United States. ${ }^{6}$ First, we are told that the definition of a short list of classic names and "canonical texts" starts to emerge only in the 1930s. It is around this time that a canon, and it is not trivial to note that its etymological root is a rule, law, or decree of the Church, begins to be established in an increasingly institutionalized sociology. Until this

6. An alternative historicist conception of the history of sociology, because it is centered on the cases of the German, French, and English traditions, can be found in Lepenies (1988). 
time, however, it was generally believed that the collective work of a mass of practitioners, and not the genial insights of half a dozen figures, was the prime condition for the advance of so recent a discipline as sociology. The self-image held by Weber, Durkheim, Spencer, and Giddings's fellow colleagues was not so much a canonical as an encyclopedic conception of science. Secondly, and perhaps due to the "rule of the small numbers" suggested by Randall Collins, according to which practitioners can memorize only a limited number of names (Collins, 1987), it was the canonical view that gained predominance. The role performed by Talcott Parsons and his The Structure of Social Action (1937/1968) in the establishment of a canonical conception was decisive but not without opposition. ${ }^{7}$ Curiously enough, Parsons would find a powerful ally in C. Wright Mills, since this author's conception of critical sociology comprehended a canonical conception of the past as well. In effect, in The Sociological Imagination (1959), Mills indicates as examples of "classic social analysts" the names of, among others, Marx, Durkheim, and Weber. Additionally, with Merton's seminal account of anomie in Social Theory and Social Structure (1949), Durkheim's canonization gained a crucial momentum. ${ }^{8}$ The trio of founding fathers was becoming the central element of sociology's self-image. Of central importance in the institutionalization of this interpretation of the history of sociology were the textbooks of the 1950s and 1960s. As Donald Levine observes, himself responsible for the translation into English of Simmel's work, it is around this time that "fresh translations, editions, and secondary analysis of classic authors became one of the fast-growing industries within sociology" (1995, p. 63). The somewhat late inclusion of Marx in the 1960s, a decade characterized by the civil rights movement in the United States and the student revolts on both sides of the Atlantic, demonstrates that the grouping of Marx, Durkheim, and Weber is a recent event and object of some theoretical reflection (see Calhoun, 1996).

In sum, the canon-formation process to which we are heirs involved the creation of a canon rather than the possibility of adopting an encyclopedic conception of scientific work, the selection of certain founding fathers, and the dissemination and institutionalization of this self-image through the professional training of the last two generations of sociologists. What "sociology" is today, its methods, its conceptual apparatus and theoretical models, its professional jargon, its problem areas - all these are the outcome of this process of creation of an institutional identity, in which national traditions played a role that was by no means negligible. One can even generalize this conclusion and assert that the successive presents of sociology are, as they were in the past and will continue to be in the future, the product of a self-legitimizing reconstructed past. Sociological theorizing, far from being an activity separated from historical self-reflexivity, as advocated by presentist-inclined authors, actually constitutes a form of theoretical argument based upon a certain positioning toward its own past. Whether we select only the aspects of past contributions that we find appropriate to the resolution of our problems, pursue a line of theory construction completely separate from historical reflection, or try to engage in dialogue with our ancestors in their own terms but in the light of our own questions, still the relation between theory and history of theory is omnipresent, even if by deliberate omission.

Richard Rorty has advocated a similar position in his analysis of the various historiographical alternatives in the study of the "great dead philosophers" (see Rorty, 1984/1998;

7. See books such as Timasheff (1955), where a gallery of other authors are discussed as well as Comte, Durkheim, and Weber.

8. An interesting historicist criticism of Parsons's appropriation of Durkheim is Pope (1973). For another historicist study, now on the work of Parsons himself, see Camic (1987). 
2000). His central contention is that there is no necessary opposition between the various types of reconstruction of past ideas (for a similar argument put forth by a sociologist, see Camic, 1996, p. 177). Apart from doxography, which should be abandoned, all four of the other types fulfill some kind of function. Hence, Skinnerian historical reconstructions, Rorty argues, by recreating the intellectual scene in which the studied authors lived their lives, help us to recognize that there have been forms of intellectual lives that are different from ours (Rorty, 1984/1998, pp. 50-51). In the case of rational reconstructions, the justification for their anachronistic character lies in the importance of being able to resort to past practitioners in order to solve present problems; in a sense, then, they become one of us (Rorty, 1984/1998, p. 68).

A third genre of reconstruction is Geistesgeschichte, whose main function is canon formation. Unlike rational reconstructions, it has to worry about anachronism, although, unlike historical reconstructions, it cannot stay in the vocabulary used by the author being studied (Rorty, 1984/1998, p. 61). Finally, Rorty proposes a fourth type of historiographical perspective that he designates as "intellectual history." The value of this kind of history of ideas is related to its controversial nature insofar as it makes us aware of the often arbitrary nature of the official canons of classic philosophers, sociologists, and so on. While studying the intellectual history of, say, the United States at the turn of the nineteenth century, we, the argument goes, might be able to recognize the importance of minor and ignored figures and to relate these forgotten authors to our heroes, whom we cannot do without. ${ }^{9}$ In a sense, then, this argument for the indispensability of intellectual heroes relates to Niklas Luhmann's thesis on the reduction of complexity-whether a hero or a symbolic figure, a classic author nevertheless simplifies and thereby fosters our discussions. The upshot of Rorty's argument is that different kinds of reconstruction of ideas from the past perform different functions; hence, one cannot say that one genre is more legitimate than the other.

Having Rorty's taxonomy in mind, my aim in the remainder of this article will thus be to discuss what I consider to be the three most influential reconstructions of Mead's ideas in sociology. Indeed, Herbert Blumer, Jürgen Habermas, and Hans Joas are the sociological thinkers whose work on Mead has contributed the most for Mead's inclusion in the sociological canon. In each section devoted to these authors, I shall examine their interpretations of Mead in the light of my initial methodological remarks; in the conclusions, I will present my own methodological view and point what I consider to be the best way to reconstruct Mead's thinking. Mead's ideas can best serve us today if one articulates a rational reconstruction with a historical one: while the latter provides the interpretation with its needed factual accuracy, the former guarantees that Mead's ideas can effectively help us solve contemporary problems. Such is the methodological foundation of a dialogical conception of sociology (see, e.g., Camic \& Joas, 2003). According to this conception, sociology is to be understood as the result of a never-ending series of dialogues between practitioners, not all of them sharing the some epoch. In other words, instead of mourning over the lack of a unified theoretical framework, sociologists should rejoice for what they have: the possibility of engaging in dialogue not only between themselves, across theoretical or methodological orientations, but also between "us" in the present and our ancestors. The possibility of learning from these conversations is something to cherish, not to complain about.

9. For the reference on the less-known historical figures, see Rorty (1998, p. 71), and for the importance of intellectual heroes, see Rorty (1998, p. 73). 


\section{G. H. Mead and Symbolic Interactionism: The Creation of a Founding Father}

In 1969, Herbert Blumer published a selection of his writings together with an introductory chapter on "the methodological position of symbolic interactionism." Blumer, who had spent the previous 40 years teaching and conducting research along the lines of a symbolic interactionist perspective, thus assuming the role "of a more or less 'loyal opposition' to the mainstream of sociology" (Joas, 1993a, p. 83), synthesized in this chapter his reconstruction of Mead's ideas from the point of view of a social scientist concerned with empirical research. The nature of symbolic interactionism is analyzed as resting on three basic premises: (1) human beings act toward things on the basis of the meanings that the things have for them; (2) the meaning of such things arises out of the social interaction between social actors; and (3) these meanings are handled in and modified through a interpretative process (Blumer, 1969, p. 2).

Furthermore, Blumer distinguishes a number of "root images" on which symbolic interactionism is grounded. The first basic image refers to the nature of human society: this is seen as consisting of "people engaging in action" (Blumer, 1969, p. 7). The nature of social interaction, the second basic image, is related to interaction between actors and not between factors imputed to them. Explaining this point further, Blumer resorts to Mead and to his distinction between "the conversation of gestures" (nonsymbolic interaction) and "the use of significant symbols" (symbolic interaction). Despite calling attention to the importance of Mead's analysis of symbolic interaction, Blumer fails to analyze the linguistic dimension of such a perspective. The third root image of symbolic interactionism refers to the nature of objects, defined as anything that can be indicated or referred to (i.e., human social life is a process in which objects are being created, transformed, and cast aside) (1969, p. 12). The human being as an acting organism is the fourth elementary idea. Contrary to the then-prevailing view that tended to see the human being as a complex organism whose behavior is a response to a number of factors, symbolic interactionism suggests "a picture of the human being as an organism that interacts with itself through a social process of making indications to itself" $(1969$, p. 14). The fifth basic idea-the nature of human action-is derived from this notion. The view of a social actor directing his own action by making indications to himself is expanded to "joint" or collective action, the main domain of sociological concern. In this case, the behavior of groups, institutions, organizations, and social classes is studied as a function of the individuals fitting together their lines of action through an interpretative process in meeting the situations in which the collectivity is called on to act. Finally, the last image is the interlinkage of action. Blumer, trying to answer the critics that accuse Mead of not dealing with macro-sociological dimensions of social life, insists on the distinctive analytical character of joint action, the societal organization of conduct of different acts of diverse participants (1969, p. 17). These are the root images of the symbolic interactionist approach. Let us now see how they are derived from Blumer's rational reconstruction of Mead's thought.

"My purpose is to depict the nature of human society when seen from the point of view of George Herbert Mead" (Blumer, 1966/1992a, p. 30-italics added). These are the words with which Blumer begins one of his most influential articles. In it, Blumer argues that Mead did not map out a theoretical scheme of human society, although such a scheme was allegedly implicit in his writings. It was Blumer's purpose to construct such a sociological theory by tracing the implications of the central elements analyzed by Mead: (1) self; (2) the act; (3) social interaction; (4) objects; and (5) joint action. My discussion of Blumer's rational reconstruction of Mead will be conducted with two questions in mind. The aim is, on the one hand, to assess the extent to which Blumer is indeed capable of putting himself in Mead's shoes, 
and, on the other, to discuss this endeavor as an element of a broader theoretical strategy of developing an alternative sociological theory to Parsons's structural functionalism.

Blumer's basic contention is that the dominant approaches to psychological and social science in the 1960s in the United States were "factorial" (i.e., tended to explain human conduct through the influence of some external factor [class, social structure, culture, and so on]). In his opinion, this entailed a severe difficulty. Human beings were depicted as mere responding organisms, incapable of self-reflection. Correctly identifying the pragmatist nature of Mead's conception of the self, Blumer emphasizes that this "process of self-interaction puts the human being over against his world instead of merely in it, requires him to meet and handle his world through a defining process instead of merely responding to it, and forces him to construct his action instead of merely releasing it” (1966/1992a, p. 32).

Discussing the Meadian notion of human action, Blumer introduces a novel elementthe idea that human beings make indications. His idea is that by making indications to themselves and by interpreting what they indicate, human beings have to delineate a line of action, note and interpret the actions of other actors, and check themselves now and then. This Blumerian notion is allegedly introduced to render Mead's scheme more clear and adequate to sociological research. However, one cannot fail to notice another function fulfilled by Blumer's reconstruction of Mead's conception of human action. Against the then-dominant formula of psychological and sociological perspectives, according to which "given factors play on the human being to produce given types of behaviour," Blumer sees Mead's model as being "fundamentally different from this formula" (1966/1992a, p. 33). In particular, human action is given by Blumer a rather secondary place in comparison to social symbolic interaction. After distinguishing between symbolic and nonsymbolic interaction, Blumer criticizes alternative schemes for being parochial. In his opinion, they try to impose "on the breadth of human interaction an image derived from the study of only one form of interaction" (1966/1992a, p. 35). His own proposal is the notion that "symbolic interaction is able to cover the full range of the generic forms of human association," and therefore "has to be seen and studied in its own right" (1966/1992a, p. 34). In a way, then, Blumer tends to subsume, against the spirit of Mead, the category of human action to that of symbolic interaction.

The next element analyzed by Mead, the implications of which are discussed by Blumer, is the concept of object. According to Blumer, Mead rooted perception and meaning in the verbal communication about definitions. In other words, Blumer interpreted the Meadian notion of object as "anything that can be designated or referred to (. . .) physical as a chair (. . .) or vague as a philosophical doctrine" (1966/1992a, p. 35). Human beings live in a world of meaningful objects, a world socially produced in that the meanings are produced through the process of symbolic interaction. In a meaningful debate for the purposes of the current discussion, Joseph Woelfel refers to Blumer's interpretation of Mead's conception of objects as having no intrinsic nature, arguing that "it makes no sense at all to try to discover what Mead 'really said' or 'really meant.' Blumer's article itself, then, (. . .), is logically absurd according to Blumer's own reasoning" (Woelfel, 1967/1992, p. 47). To this, Blumer answers that "[ $t]$ o dismiss so cavalierly the need of understanding accurately the thought of (. . .) Mead and to imply that any version by any commentator of such a man's thought qualifies as a depiction of that thought, constitutes scholarship at its lowest level" (Blumer, 1967/1992b, p. 51). This rejection of relativism by Blumer is especially significant in the light of his own purpose of constructing an alternative sociological theory "from the point of view of" Mead. As we have been seeing, not only is the identification of the central elements of Mead's thought controversial (human language is missing; historical evolution is absent), but also their treatment is clearly functional to the establishment of symbolic interactionism as a sociological theory and a program of empirical research in its own right. 
This is particularly clear in Blumer's analysis of the fifth and last element of Mead's scheme, joint action (Mead's "social act"). In an almost indistinguishable presentation of his own thought and Mead's ideas, Blumer suggests that joint action is a concept that refers to the larger collective form of action that is constituted by the fitting together of the lines of behavior of the individual actors, ranging from a simple collaboration of two individuals to complex, large-scale alignments of acts in huge institutions or organizations: "Mead saw joint action, or the social act, as the distinguishing characteristic of society. For him, the social act was the fundamental unit of society" (1966/1992a, p. 36). From these five elements (self, the act, social interaction, objects, and joint action), Blumer concludes that one can sketch a picture of human society in terms of action, a picture that defied the then-dominant Parsonian structural functionalism. As he asserts, "[i]t is perhaps unnecessary to observe that the conception of human society as structure or organization is ingrained in the very marrow of contemporary sociology. Mead's scheme definitely challenges this conception" (1966/1992a, p. 39). Or should he have said "my rational reconstruction of Mead's ideas"?

At the end of the 1970s, Blumer was invited to write an article on Mead in a book suggestively entitled The Future of the Sociological Classics (1981). In this rather historically minded publication, ${ }^{10}$ Blumer once again discussed Mead's contribution to contemporary sociology. This article is relevant for two different reasons. First, in it Blumer recognized that, despite a wealth of empirical research in the field of symbolic interactionism using Meadian conceptual tools, Mead as a classic was still on the periphery of sociological attentions (see Blumer, 1981, p. 136). As is seen in the next section, one of Habermas's accomplishments was to place Mead in the sociological canon. Second, in this article, Blumer reiterated his reading of Mead as well as his fundamental theoretical strategy. In fact, Mead's conception of human societies as formed by organisms with minds and selves was analyzed in terms of its originality and empirical value as against eight competing alternatives (again, the so-called "factorial theories") (see Blumer, 1981, pp. 153-159). This discussion gives us a clear picture of the symbolic interactionist appropriation of his ideas, despite some misunderstandings of Mead's thought. For instance, Blumer stressed that "in the case of congenitally deaf children who do not learn a language," a "child would not develop a self" (Blumer, 1981, p. 141). However, Mead clearly stated that "the vocal gesture is not the only form which can serve for the building-up of a 'me,' as is abundantly evident from the building-up gestures of the deaf-mutes" (Mead, 1912, p. 405).

Nevertheless, the symbolic interactionist reconstruction of Mead's thought has the merit of having fostered an immensely fruitful program of empirical research, Blumer's main concern in terms of his fundamental theoretical strategy. Rather than trying to produce an accurate historical account of Mead's social theory, Blumer's ultimate motive was to create an original model of sociological analysis from specific elements of Mead's thought—namely, the notions of self, of social act, and of interpretation and indication. Thus, I agree with Gary Alan Fine that Blumer should be seen not as the interpreter of Mead's works, but rather as a theorist "in his own right" who constructed his theoretical and methodological position by reference to Mead among other authors (see Fine, 1990).

In the light of my initial methodological remarks, it seems clear that Blumer's rational reconstruction of Mead exemplifies the connectedness between the history and the systematics of sociological theories. In the United States, during the reign of Parsons's structural functional-

10. The editor, Buford Rhea, stresses in the introduction that "the new generation of sociologists recognizes their [the classics'] importance" (Rhea, 1981, p. ix), rejecting Merton's separation between the history and systematics of sociological theory. In fact, all contributors were asked to comment on the contemporary relevance of each classic studied. 
ism, Blumer was probably the only alternative figure. Both authors made use of sociology's past to legitimize their own theoretical strategies: if Parsons contributed decisively to the canonization of Weber and Durkheim (and, by opposition, of Marx), Blumer, an assumed heir of American pragmatism (see Tucker, 1988), was responsible for the placing of Mead in the sociological canon. As I have tried to demonstrate, the price to pay for such canonization was a historically untenable interpretation of Mead's thinking. In my opinion, the challenge lies in reconciling a historically accurate account of Mead's writings with a theoretical project that gives life, so to speak, to Mead's ideas. The history of sociological theories and their systematic substance are but two faces of the same coin, since a historical re-examination of Mead's thought will certainly entail noticeable theoretical implications. Blumer's greatest contribution to Meadian scholarship was the creation of a fruitful program of sociological research at the cost of a somewhat truncated image of its founding and inspiring figure. Despite claiming to be following Mead's implicit methodological position, from "Mead's point of view," it seems that Blumer explicitly imposed his own point of view on Mead's writings. If Blumer's reassessment of Mead can be easily understood within the American intellectual context, ${ }^{11}$ Habermas's relation to American philosophical pragmatism requires some preliminary remarks.

\section{Habermas And Mead: Historiography with Systematic InTENT}

Habermas's appropriation of American pragmatism is especially noteworthy since the first generation of the Frankfurt School, in exile in the United States during the 1930s and 1940s, was particularly indifferent to native currents of thought. Critical theorists such as Theodor Adorno and Max Horkheimer never seriously acknowledged either Parsons's 1937 The Structure of Social Action or John Dewey's political writings. Unlike Hannah Arendt or Alfred Schütz, the relationship between the critical theorists associated with the Frankfurt School and the American social and political theorists was not a fruitful one. When seen in this light, Habermas's attempt to achieve a synthesis of the American and Frankfurt traditions cannot be underestimated. In particular, his attempt to draw on the pragmatist philosophy of science in his argument against positivism in the 1960s (see Habermas, 1972/1998), his endeavors to reconcile Marxist democratic thought with American pragmatism's political insights (see Habermas, 1986), and his paradigmatic shift from instrumental to communicative action and rationality (see Habermas, 1981/1987) constitute long-term traits of Habermas's theoretical profile.

This section discusses Habermas's rational reconstruction of Mead in four successive stages. First, Habermas's theoretical strategy is assessed in order to clarify his conception of "historiography with a systematic intent." Second, I examine the relation between rational reconstructions and social criticism by discussing Habermas's model of reconstructive science. An analysis follows of Habermas's reconstruction of Mead both in The Theory of Communicative Action (1981/1987) and in Postmetaphysical Thinking (1988). The section concludes with an assessment of the Habermasian rational reconstruction of Mead's ideas in the light of the methodological considerations set out at the beginning of the article.

One of Habermas's first writings on the history of philosophical ideas is a postscript to his famous critique of positivism, Knowledge and Human Interests (1972/1998). Still concerned with that controversy, Habermas explains that one way of denouncing scientism's (or positivism's) denial of reflection consists of "reconstructing the prehistory of modern posi-

11. Rejecting Parsons's proposed synthesis of European social and economic theories, Blumer resorted to pragmatism, a distinctively American tradition of thought to which, as I have pointed out, he was intellectually related. 
tivism" (Habermas, 1972/1998, p. 353). Following the "new history of science" inaugurated by Kuhn in the early 1960s, Habermas attributed to the history of science (natural and human sciences alike) the status of a critical self-reflection. The reason is simple. While reconstructing the past of science, scientists must engage in a self-reflexive activity toward their ancestors. Of course, for those scientists who, like Merton, separate the history of a theory from its systematic content, this self-reflective activity makes no sense. Thus, in order to avoid this circularity (one has to value self-reflection in order to see it as a rightful activity), Habermas stressed the need for a systematic justification of such self-reflective histories. In his opinion, the confrontation of science theory with the history of science has shown that the task of a "rational reconstruction of the history of science no longer permits the typically scientistic omission of a logical analysis of the development and use of theories" (Habermas, 1972/1998, p. 353). Thus, the systematic justification for conducting historical studies of science lies in the interdependence between history and theory - a logical analysis of the process of evolution of the latter demonstrates the extent of the importance of the former.

Yet having said this, it must be admitted that Habermas's central theoretical concern was not the history of science, nor even the history of ideas, but a specific kind of interpretative social science. His model of social science stands between a positivistic approach, which denies the methodological uniqueness of the social and human sciences, and a hermeneutical perspective, which questions the appropriateness of the notion of science when applied to the humanities. As he put it in On the Logic of Social Sciences (1967/1996), his approach can be described as "hermeneutically enlightened and historically oriented functionalism" (Habermas, 1967/1996, p. 187). The basic idea was that of providing a normative reconstruction of the more advanced states for the learning processes of modern capitalist societies in the light of which systemic disturbances could be identified. This normative reconstruction was to be grounded on a theory of language, whose first versions appeared during the early 1970s (see, e.g., Habermas, 1970, 1976/1991), and that was published in its most developed form in The Theory of Communicative Action (1981/1987). Like Parsons half a century before, Habermas sought to synthesize in his magnum opus an impressive set of sociological and philosophical contributions in order to develop a theory of society with a practical import. Despite the fact that Habermas wrote it more as a text on systematic theory than on the history of Western social theory, this synthesis assumed the form of a grand narrative. ${ }^{12}$

In this two-volume book, Habermas argued for an interpretative approach within the social sciences since this is the only methodological perspective capable of coping with the symbolically prestructured reality that constitutes their main object of study. Hence, the objects of study of the social sciences are embedded in "complexes of meaning" that the social scientist can analyze only by means of a systematic confrontation with his pretheoretical knowledge as a social actor. As Habermas explained:

The social scientist basically has no other access to the lifeworld than the social-scientific layman does. He must already belong in a certain way to the lifeworld whose elements he wishes to describe. In order to describe them, he must understand them; in order to understand them, he must be able in principle to participate in their production; and participation presupposes that one belongs. (Habermas, 1981/1984, p. 124)

The implications of such a methodological approach for the purposes of my argument are far-reaching. First, if one aims at interpreting human action, the unavoidable requirement

12. For a discussion on Habermas's project of reconciling American pragmatism and Marxism in a deliberative democratic theory, see Antonio (1990, p. 100). 
is to make clear the reasons the studied actors would give for their actions. Second, this, in turn, cannot be separated from the interpreter's taking a position on the validity claims connected with that action: "An interpreter cannot, therefore, interpret expressions connected through criticizable validity claims with a potential of reasons (and thus represent knowledge) without taking a position on them" (Habermas, 1981/1984, p. 116). In other words, as Kenneth Baynes asserted, understanding the reasons that led an actor to act in some particular way entails taking a position on the validity of such reasons according "to our own lights" (Baynes, 1990/1991, p. 124). Third, Habermas stressed that the condition of intelligibility of the reasons advanced by social actors to explain their action is a process of "rational reconstruction" by the interpreter. That is, since these reasons can be translated into arguments ("I did that because ... and then ..."), we understand them only when we recapitulate (i.e., rationally reconstruct them in the light of our standards of rationality).

However, one should not be misled into thinking that Habermas is abandoning any hopes of constructing a general social theory. To the crucial question "How can the objectivity of understanding be reconciled with the performative attitude of one who participates in a process of reaching understanding?" (1981/1984, p. 112), Habermas suggested the following answer. The objectivity of interpretations of human action can be secured as long as one submits to logical analysis the "general structures of the processes of reaching understanding," shared by both interpreter and actor. The reconstruction of such general structures is one of the goals of The Theory of Communicative Action.

The starting point of the third topic in this section is the crucial turn suffered by Habermas's argumentation in the passage leading from the first to the second volume of that book. At the end of the first volume, Habermas discussed what he designated as critical theory aporias, whose most startling example was Theodor Adorno's Negative Dialektik (1966). However, Habermas found something positive in the difficulties met by the tradition of critique of rationalization (a tradition inaugurated by Weber and developed by Lukács and the Frankfurt School), when he observed that " $[t]$ here is something to be learned from these problems; indeed they furnish us with reasons for a change of paradigm within social theory" (1984, p. 366) and concluded that "[w]hereas the problematic of rationalization/reification lies along a 'German' line of social-theoretical thought (. . .), the paradigm change that interests me was prepared by George Herbert Mead and Émile Durkheim” (1981/1984, p. 399). In other words, Mead and Durkheim were seen as the sociological classics that had paved the way for a linguistic turn in the social sciences.

In order to transcend the neo-Marxist tradition that interpreted the process of rationalization of modern Western societies as a phenomenon of conscience reification, Habermas resorts to Mead and Durkheim. Of the latter, Habermas stressed the importance of the theory of social solidarity (which unites the problem areas of social integration and systemic integration), ${ }^{13}$ of the former, a foundation of sociology as a theory of human communication. In particular, Habermas proposed a theory of action that, like Mead's, projected an ideal communication community. This utopia allowed him to reconstruct an original intersubjectivity that fostered both mutual understanding and self-knowledge.

When Habermas enumerates the elements comprehended in his analysis of the basic conceptual structure of the normatively regulated and linguistically mediated interaction proposed by Mead, he identified, like Blumer decades before, two distinct types of human interaction. I refer to the interaction mediated by gestures and controlled by instincts and the in-

13. Social integration refers to the process of symbolic reproduction of the lifeworld, whereas systemic integration is related to the material reproduction of society, which covers both the systemic and symbolic dimensions of human societies. 
teraction symbolically mediated in signal languages. Unlike Blumer, however, Habermas considered this latter element not only to be the most important, but also to be lacking an analytical development of a theory of language. If Blumer resorted to Mead for the purposes of an empirical social science perspective concerned with the analysis of human interaction, Habermas sought to reconstruct Mead so that a linguistically minded sociological theory could be developed.

At this point, it is important to note Hans Joas's criticism that it is a serious simplification to focus an analysis only on these two dimensions of Mead's proposals: “. . . his [Mead's] works cover the entire spectrum ranging from the dialogue of significant gestures to complex scientific or public political discussions" (Joas, 1993b, p. 137). The same is to say, Mead's interest in the origins of human communication was far from being his only interest, as Habermas's reading suggests. This debate between Habermas and Joas will be resumed and developed in the next section.

An even more focused criticism can be leveled at Habermas's interpretation of Mead in Postmetaphysical Thinking. In a chapter entitled "Individuation through Socialization: On Mead's Theory of Subjectivity," Habermas stressed the inability of the entire Western sociological tradition to account for the process of individuation. The solution for such a difficulty lies in Mead's theory: "The only promising attempt to grasp the entire significance of social individualization in concepts is, I believe, initiated in the social psychology of George Herbert Mead" (Habermas, 1988, p. 151). In particular, Mead's distinction between the two phases of the self (the "I" and the "me") seems to be the key to explaining the "postconventional egoidentity" that characterizes the modern individual of contemporary societies. Interpreting Mead's notion of "me" as an "identity formation that makes responsible action possible only at the price of blind subjugation to external social controls" (Habermas, 1988, p. 182), Habermas was able to confront it with an "I" responsible for projecting the "context of interaction that first makes the reconstruction of a shattered conventional identity possible on a higher level" (Habermas, 1988, p. 178). The "I" is able to do this because it anticipates a universalistic, idealized communication community. Against the conventionality of the "me," Habermas appealed to an "I" that anticipates a larger self. Although this dichotomy might be useful for Habermas's purposes, it is doubtful that it is a faithful usage of Mead's concepts (see also Aboulafia, 1995, p. 106). In other words, Habermas constructed this dichotomy at the expense of the dialectic relationship between the two phases of the self envisaged by Mead.

As has been seen, in The Theory of Communicative Action, Habermas contended that social theory after Hegel evolved in three separate branches. The first was followed by Dilthey, Husserl, Weber, and Parsons and came to constitute a general theory of action (power being the central steering medium). The second, developed by economic theory, led to systems analysis through the notion of an instrumental order steered by the medium of money. The third was concerned with the structural features of symbolically mediated interaction, and its main figure was Mead. Since Habermas argued that Mead's theory lacks a conception of a symbolic prelinguistic root of communicative action, he had to resort to Durkheim in order to fill this gap with the latter's theory of collective consciousness. From the point of view of my initial methodological remarks, this historical account constitutes an example of a rational reconstruction of Western modern social theory, in which Mead performs one of the central roles. It is in this precise sense that I contend that Habermas is the author that has done the most for Mead's inclusion in the canon of sociological classics. Yet, as I have also tried to demonstrate, such a canon is socially constructed and historically contingent. Some would therefore argue that the study of Mead would be a symptom of presentism. I do not agree. It is legitimate to study those authors whose ideas turned out to be more influential than others, 
even if the process by which this takes place is a social product of specific contexts. Then again, so is science.

My criticism of Habermas's rational reconstruction of Mead's ideas is that, at least in some crucial cases, it seems not to respect the spirit of Mead's work. This is not a mere historicist criticism. Beyond mere intentionality (what Mead intended by writing or saying what he wrote or said) or historical accuracy (the context-bound nature of social and political ideas), what I am questioning is the fact that Mead's thinking seems to have been interpreted solely in the light of Habermas's theoretical interests (producing a theory of communicative action built on a vast number of legitimizing contributions). Two questions immediately arise. First, Habermas does not let himself learn from Mead as much as he would if he had engaged with Mead in dialogue in Mead's own terms. Second, and as a result, if it is true that Habermas gained something with his presentist reading, he nevertheless lost something else. I refer to Mead's much-neglected writings on the "material reproduction of society" and on a "sociolinguistic" foundation for radical democratic politics that could have been of great value to Habermas's own undertakings. Such is the price one pays when one opts for a monological methodology over a dialogical one, the only one that allows theorists to question their present beliefs and learn from the past.

As I have been trying to demonstrate, the way the history of social theory is reconstructed is directly linked to the systematic objectives of the social scientist in question. In Blumer's case, the reconstruction of Mead's legacy was used to legitimize a novel and alternative sociological perspective to Parsonian structural functionalism-symbolic interactionism. In the case of Habermas, Mead is reconstructed so that the linguist turn suffered by philosophy in the 1960s can be expanded to sociology through a paradigm shift—from purposive or instrumental action to communicative action. In both cases, factual accuracy was not the main concern; still, factual inaccuracies can bear significant theoretical implications. For instance, what would become of Habermas's rational reconstruction if one demonstrated that the prelinguistic root allegedly lacking in Meadian social theory is more a question of thematic than systematic omission? How could he maintain the need for resorting to Durkheim? Moreover, Habermas's criticism of Mead for having allegedly neglected the process of "material reproduction of society" can be said to be only that, an allegation with no substantial evidence to corroborate it. ${ }^{14}$

My contention is that even if a social theorist is engaged in theory construction (as Habermas was), historical accuracy is a prerequisite of rigorous and sound theorizing. The critical distance one might gain from one's own beliefs is another advantage resulting from the adoption of a historically minded methodology. In the particular case of Habermas, one can even say that his theoretical interests could have been better served if only he had allowed himself to engage in dialogue with Mead. Such an imaginary dialogue could have given Habermas exactly what he was looking for-namely, the communicative social theoretical basis for a deliberative democratic theory. This is not to say that Habermas should be criticized for having interpreted Mead in a selective way. After all, to theorize is, to a certain extent, exactly to be able to select the most relevant aspects of your predecessors in the light of the problem you wish to solve. Rather, my contention is that had Habermas engaged in dialogue with Mead in Mead's own terms, he would have been able to learn much more than he did. For instance, he would have been able to escape the conventional view, inaugurated by Blumer and the symbolic interactionists, that Mead did not have much to say on the "material reproduction of society." What I wish to emphasize is that a historically minded account

14. In a forthcoming article in Sociological Theory, I elaborate on these two points. 
of sociology's past is a crucial and unavoidable dimension of social theory construction. The history and systematics of sociological theories should be seen as a sort of Janus-faced process. How should one proceed so as to achieve a balanced interpretation of Mead that is not only historically accurate, but also theoretically useful? This is the explicit goal of Hans Joas, the subject of the next analysis.

\section{JoAs And Mead: From a Biographical Portrait to a Theory of Action}

In this last section on the rational reconstructions of Mead's thought, I discuss the proposals put forth by Hans Joas. I start by presenting Joas's criticisms of Blumer and Habermas based on his understanding of the relation between the history of sociological theory and its systematics, which will provide an opportunity to assess the relative strengths and weaknesses of these three reconstructions. Then, I turn to Joas's own treatment of Mead, a reconstruction characterized by a somewhat questionable assumption of systematic coherence on the part of Mead - was Mead really trying to develop a systematic account of some core concepts and ideas throughout his career or is this another mythology of coherence, to use Skinner's expression? ${ }^{15}$ Finally, and restating once again my belief in the interpenetration of history and theory, I discuss the theory of creative action proposed by Joas in the light of his historically minded (but nevertheless) rational reconstruction of Mead. To what extent that particular reading of Mead was functional to Joas's own theoretical endeavor is the last line of inquiry I would like to pursue.

The reasons put forward by Joas to justify the need for an exact knowledge of the history of Mead's anthropological theory of symbolic interaction are particularly telling of his position on the historicism vs. presentism debate. In a remark that has a bearing on this article, Joas stresses the "unfinished and accidental form in which Mead's mature work has been handed on to us," which demands and justifies his attempt to "bring together and to systematize all of the material contained in the relevant articles written by Mead himself" (1980/1997, p. 90, italics added). In fact, this systematization must assume the form of a rational reconstruction that helps the reader to understand the "emergence of a concept from which implications were to be drawn and utilized only much later, in symbolic interactionism [Blumer] and in a reconstruction of historical materialism influenced by interaction theory [Habermas]" (1980/1997, p. 91). In other words, Joas argues that an accurate historical reconstruction of a classic author's thought is not only of interest in terms of the history of theory but also in terms of its systematics. ${ }^{16}$ Moreover, since Joas devoted a substantial part of his career to the study of Mead, pragmatism, and symbolic interactionism, his insights on Blumer's and Habermas's reconstructions of Mead are especially pertinent here.

As to the first case, Joas's assessment of the symbolic interactionist program of research pursued by Blumer has two different dimensions. First, Joas is critical of some aspects of this

15. As Skinner explains, "If the basic paradigm for the conduct of the historical investigation has been conceived as the elaboration of each classic writer's doctrines on each of the themes most characteristic of the subject, it will become dangerously easy for the historian to conceive it as his task to supply or find in each of these texts the coherence which they may appear to lack. (...) The inevitable result (...) will still be a form of writing which might be labelled the mythology of coherence" (Skinner, 1969, p. 16).

16. This very same methodological position is restated when Joas discusses Habermas's reconstruction of Durkheim, in The Theory of Communicative Action. After criticizing Habermas for "violating the spirit of Durkheim's work," Joas considers Habermas's "attempt to describe reconstructively, from the internal perspective of the members, what Durkheim called the conscience collective" (Habermas, 1987, p. 133), to be an "impossible undertaking" (Joas, 1993b, p. 133). 
perspective. On the one hand, he criticizes "its reduction of the concept of action to that of interaction, its linguistic attenuation of the concept of meaning, and its lack of any consideration of evolution and history" (Joas, 1980/1997, p. 7). On the other, he criticizes its limitation to phenomena of interpersonal immediacy and its underestimation of questions of power and domination (Joas, 1993a, p. 84). Second, Joas considers symbolic interactionism to be a sociological perspective focused on symbolic processes of social interaction. Social relations are thus jointly and reciprocally defined. However, Joas suggests that the true significance of this set of ideas and its potential theoretical fecundity is related to the "Chicago school of sociology," to which symbolic interactionism is but a partial heir. In other words, Blumer is seen by Joas as someone who developed philosophical pragmatism in a limited sociological form. According to Joas, sociology can benefit much more from this theoretical system if it abandons Blumer's program and rewrites its history so that a different and more ambitious sociological perspective may be developed.

As far as Habermas's reconstruction of Mead is concerned, Joas starts by stressing that "the positions which Habermas allocates the classics within the history of the theory" (Joas, 1993b, p. 131) have important theoretical consequences. In Mead's case, these consequences are related to the charge that he neglected the systemic integration of modern societies. This is a particularly important criticism since it enables Habermas to link Mead and Durkheim: whereas the former explained seminally the processes of social integration, the latter offered us a cogent theory of the material reproduction of society. Habermas's rational reconstruction of Mead, emphasizing his "idealistic deviations," is clearly functional to his own theoretical purposes.

However, as Joas correctly stresses, Mead's neglect of the processes of systemic integration (such as economics, war, or political struggles) is more thematic than systematic. That is, the fact that Mead did not publish extensively on these topics does not mean that his social theory is inadequate for coping with those sort of questions. ${ }^{17}$ The very distinction between social and systemic integration used by Habermas is strange to Mead's thought. The idea that the processes of social integration should be studied by a theory of action and the processes of systemic integration by a functionalist theory of systems is completely alien to Mead. As Joas puts it, "Habermas imputes to the concept of social integration a meaning of "lifeworldly,' interpersonal immediacy not to be found in Mead's work" (1993b, p. 138). In sum, it is because Habermas restricts the sociological theory of action to the sphere of the lifeworld that he criticizes Mead for being idealistic and then resorts to Durkheim. If only Habermas's understanding of the scope of a sociological theory of action were wider (as it is in Joas's case), his reconstruction of Mead would surely be different. It is now clear how Habermas's theoretical framework decisively determines the way he writes the history of sociological theory.

Joas's intellectual biography of Mead can be seen as an attempt to avoid this kind of difficulty. His strategy can be described as follows. First, one has to produce a historically accurate account of the ideas of the classic author in question. Second, one is entitled to apply this historical reconstruction to theory production. Thus, a balance between the history of ideas and theory construction is achieved. Of course, such balance is always an approximate achievement. If one takes Joas's interpretative key, the concept of "practical intersubjectivity" (1980/1997, p. 13), a notion that tries to encapsulate both the "structure of communicative re-

17. As I show in a forthcoming article in the History of the Human Sciences, Mead's thinking can be better described as a building with three clear research areas: science, social psychology, and politics. From this point of view, it is not even the case that Mead did not write extensively on the processes of systemic integration. In the George Herbert Mead Papers Archive at the University of Chicago, there are over 250 pages of unpublished materials on these topics, which actually exceeds in length Mead's published articles on the same subject. 
lations between subjects" and its origin in the "joint activity of human subjects to achieve ends set by their life needs" (1980/1997, p. 14), one can see that historical rigor gives way to theoretical productivity. Despite being absent from Mead's writings, Joas's notion of "practical intersubjectivity" not only enables him to interpret "Mead's work, in its coherence and its significance" (1980/1997, p. 145), but is also the theoretical axis around which his attempt to set forth the ideas of pragmatism in terms of contemporary social theory is developed. I am referring to the book The Creativity of Action, where Joas suggests the thesis that "a third model of action should be added to the two predominant models of action, namely rational action and normatively oriented action" (1992/1996, p. 4). This third model of action emphasizes the creative dimension of human action, or, in other words, the notion of "practical intersubjectivity" is seen as the solution for the impasse faced by contemporary sociological theories of action. The idea that in the early 1980s helped Joas to reconstruct Mead's thought and to suggest a reappraisal of American pragmatism is given, a decade later, the theoretical status of the core concept of a novel theory of action. Again, the interpenetration of history and theory is undeniable.

\section{CONCLUSIONS}

The above discussion of the three rational reconstructions of Mead's social thought can now be followed by a comparison of Joas's proposal with those of Blumer and Habermas. As I have attempted to show, the image Blumer tried to ascribe to Mead was determined by Blumer's own theoretical strategy of creating an alternative program of research to Parsonian structural functionalism and Merton's functional analysis. The justificatory procedures of symbolic interactionists often included a reference to their founding father, Mead. However, since they were sociologists and not historians of ideas, their prime objective was empirical social research and not the historical reconstruction of sociology's past. This was the case with Blumer, who completely ignored fundamental dimensions of Mead's legacy, such as human language and an evolutionary conception of human development. Had Blumer emphasized these aspects of Mead's writings, symbolic interactionism as a whole would have followed completely distinct research paths. In comparative terms, Joas's analysis of Mead - an intellectual biography, properly speakingcan be considered to be a much more reliable and faithful description of his thought, even though it did not trigger a fraction of the empirical research resulting from symbolic interactionism. Sociology's internal politics apart, the fact is that symbolic interactionism stands today, after Blumer's demise, as a fruitful tradition of empirical research, in the United States as well as in Europe, a tradition that seems to be able to cope with the recent trend of synthetic movements (see Fine, 1993).

Habermas's reconstruction must be seen as an attempt to rewrite the history of Western social theory so that the major dichotomies that have led to theoretical and empirical research dead ends are overcome. A number of past authors are invited by Habermas to contribute to the resolution of these problems. When in dialogue, these authors help each other by filling the gaps left open by others, by solving previous authors' dilemmas, and so on. The task of the social theorist is, according to this conception of "history with systematic intent," to gather a canon of past authors so that present-day problems may be solved with their help. As I have tried to show, Habermas's theoretical agenda would be better served had he opted for a more historically minded methodology. In that case, he could have seen in Mead the answer for some of the questions that preoccupied him for so long. I refer, in particular, to Habermas's desire to supplement a Marxist analysis with pragmatism's radi- 
cal democratic insights, within a social theoretical framework that gives communication a central role. Following a presentist strategy, Habermas was able to see in Mead the key for the paradigmatic transition from the consciousness paradigm to the paradigm of communicative action. Had he mobilized a historicist strategy, he could have seen that Mead's writings on democratic politics, though less developed than Dewey's (Habermas's major source of inspiration concerning radical democratic politics), are, nevertheless, founded upon a communicative social theory. Such a "socio-linguistic" foundation of radical democracy is but one of Mead's much-neglected contributions for contemporary deliberative democrats, Habermas included.

From these remarks, Joas's rational reconstruction of Mead stands out as the more sensitive to historical accuracy, despite being less ambitious than Habermas's and less fruitful than Blumer's. Nevertheless, one can identify two different parts in Joas's book. In the first half, Mead's thought is reconstructed from the point of view of the evolution of his ideas, starting with a discussion of his personal biography and leading to a comprehensive study of the concept of "symbolic interaction." In the second half, Joas suddenly abandons this presentation strategy and systematically discusses various topics: ethics, the constitution of the physical object, the theory of time, and philosophy of science are the areas successively analyzed. What this inconsistency entails in terms of Joas's contribution to this debate is that his reconstruction of Mead meets its purposes only halfway. By reading Joas's account, one can learn how some of Mead's ideas evolved over time and grasp the internal coherence of certain thematic areas. What one cannot see, however, is how Mead's system of thought evolved during the course of his career. ${ }^{18}$

At the beginning of this article, I criticized Merton's view that the history of the theory and the "systematics" of the theory should be dealt with separately. In fact, this article tries to demonstrate precisely the opposite: theory building in sociology has much to gain from incorporating historically minded reconstructions of our founding fathers. At this point, however, I would like to retain another aspect of Merton's conception of science, his rejection of what he called "theoretical monism" in favor of a pluralistic view of sociology (Merton, 1975). It is in Donald Levine's dialogical perspective that one finds the answer for connecting, on the one hand, the rejection of the separation between theory and history of theory, and, on the other hand, the endorsement of a pluralistic conception of sociological theories (see Camic \& Joas, 2003; Levine, 1995). Dialogue between current practitioners and our forerunners is only possible if one carefully reconstructs the context where figures like Marx, Weber, Simmel, Durkheim, or Mead developed their analyses of modernity. In the case of Mead, a balance between historical rigor and productive theoretical work is to be achieved only if one reconciles a historical reconstruction, so that its unfolding throughout the years can be grasped, with a thematic reconstruction, in order to identify his major research areas and topics of interest. I thus believe that to reconstruct the historical origins of the apparently incommensurable premises of the rival arguments deployed in current sociological debates is the best way of bringing some order to contemporary sociological theory (see MacIntyre, 1981, 1984/1998). This, I argue, would avoid the problems associated with "presentism," without falling into the opposite error of, positivistically, trying to separate theory from its historythe history that gives theory its meaning.

18. The careful study of Mead's published writings (1932/2002, 1934/1997, 1936/1972, 1938) is not sufficient to grasp either the thematic organization or the genetic evolution of Mead's system of thinking. Given the poor editorial situation of Mead scholarship, one has to resort to archival research, in particular in the aforementioned George Herbert Mead Papers Archive. 


\section{REFERENCES}

Aboulafia, M. (1995). Habermas and Mead: On universality and individuality. Constellations, 2, 94-113.

Adorno, T. (1966). Negative dialektik. Frankfurt am Main: Suhrkamp.

Alexander, J. (1982). Theoretical logic in sociology. Vol. 1: Positivism, presuppositions, and current controversies. London: Routledge and Kegan Paul.

Alexander, J. (1993). The centrality of the classics. In A. Giddens \& J. Turner (Eds.), Social theory today (pp. 11-57). Cambridge, UK: Polity Press. (Original work published 1987)

Alexander, J., \& Sciortino, G. (1996). On choosing one's intellectual predecessors: The reductionism of Camic's treatment of Parsons and the institutionalists. Sociological Theory, 14, 154-171.

Antonio, R. (1990). The decline of the grand narrative of emancipatory modernity: Crisis or renewal in neo-Marxian theory? In G. Ritzer (Ed.), Frontiers of social theory: The new syntheses (pp. 88-116). New York: Columbia University Press.

Baehr, P., \& O’Brien, M. (1994). Founders, classics and the concept of a canon. Current Sociology, 42, 1-148.

Baynes, K. (1991). Rational reconstruction and social criticism: Habermas's model of interpretive social science. In M. Kelly (Ed.), Hermeneutics and critical theory in ethics and politics (pp. 122-145). Cambridge, MA: MIT Press. (Original work published 1990)

Blumer, H. (1937). Social psychology. In E. Schmidt (Ed.), Man and society (pp. 144-198). New York: Prentice-Hall.

Blumer, H. (1969). Symbolic interactionism: Perspective and method. Berkeley, CA: University of California Press.

Blumer, H. (1981). George Herbert Mead. In B. Rhea (Ed.), The future of the sociological classics (pp. 136-169). London: George Allen and Unwin.

Blumer, H. (1992a). Sociological implications of the thought of G. H. Mead. In P. Hamilton (Ed.), George Herbert Mead: Critical assessments (Vol. 2; pp. 30-46). London: Routledge. (Original work published 1966)

Blumer, H. (1992b). Reply to Woelfel, Stone and Farberman. In P. Hamilton (Ed.), George Herbert Mead: Critical assessments (Vol. 2; pp. 51-52). London: Routledge. (Original work published 1967)

Boucher, D. (1985). Texts in context. Revisionist methods for studying the history of ideas. Dordrecht: Martinus Nijhoff Publishers.

Calhoun, C. (1996). Whose classics? Which readings? Interpretation and cultural difference in the canonization in sociological theory. In S. Turner (Ed.), Social theory and sociology. The classics and beyond (pp. 70-96). Oxford, UK: Blackwell Publishers.

Camic, C. (1981). On the methodology of the history of sociology: A reply to Jones. American Journal of Sociology, $86,1139-1144$.

Camic, C. (1987). The making of a method: A historical reinterpretation of the early Parsons. American Sociological Review, 52, 421-439.

Camic, C. (1989). Structure after 50 years: The anatomy of a charter. American Journal of Sociology, 95, 38-107.

Camic, C. (1992). Reputation and predecessor selection: Parsons and the institutionalists. American Sociological Review, 57, 421-445.

Camic, C. (1996). Alexander's antisociology. Sociological Theory, 14, 172-186.

Camic, C., \& Joas, H. (Eds.). (2003). The dialogical turn. New roles for sociology in the postdisciplinary age: Essays in honor of Donald N. Levine. Lanham, MD: Rowman \& Littlefield.

Collins, R. (1987). The sociology of philosophies. Cambridge, UK: Cambridge University Press.

Connell, R. W. (1997). Why is classic theory classical? American Journal of Sociology, 102, 1511-1557.

Cook, G. A. (1993). George Herbert Mead: The making of a social pragmatist. Urbana, IL: University of Illinois Press.

Dunn, J. (1968). The identity of the history of ideas. Philosophy, 43, 85-116.

Feffer, A. (1990). Sociability and social conflict in George Herbert Mead's interactionism, 1900-1919. Journal of the History of Ideas, 51, 233-254.

Feffer, A. (1993). The Chicago pragmatists and American progressivism. Ithaca, NY: Cornell University Press.

Fine, G. (1990). Symbolic interactionism in the post-Blumerian age. In G. Ritzer (Ed.), Frontiers of social theory: The new syntheses (pp. 117-157). New York: Columbia University Press.

Fine, G. (1993). The sad demise, mysterious disappearance, and glorious triumph of symbolic interactionism. Annual Review of Sociology, 19, 61-87.

Fine, G., \& Kleinman, S. (1992). Interpreting the sociological classics: Can there be a "true" meaning of Mead? In P. Hamilton (Ed.), George Herbert Mead: Critical assessments (Vol. 1; pp. 214-232). London: Routledge. (Original work published 1986)

Gerstein, D. (1983). Durkheim's paradigm: Reconstructing a social theory. In R. Collins (Ed.), Sociological theory (pp. 234-258). San Francisco, CA: Jossey-Bass.

Habermas, J. (1970). Towards a theory of communicative competence. Inquiry, 13, 360-376.

Habermas, J. (1984). The theory of communicative action: Reason and the rationalization of society (Vol. 1). Cambridge, UK: Polity Press. (Original work published 1981)

Habermas, J. (1986). Autonomy and solidarity. London: Verso.

Habermas, J. (1987). The theory of communicative action: Lifeworld and system: the critique of functionalist reason (Vol. 2). Cambridge, UK: Polity Press. (Original work published 1981)

Habermas, J. (1988). Postmetaphysical thinking: Philosophical essays. Cambridge, UK: Polity Press. 
Habermas, J. (1991). Communication and the evolution of society. Cambridge, UK: Polity Press. (Original work published 1976)

Habermas, J. (1996). On the logic of social sciences. Cambridge, MA: MIT Press. (Original work published 1967)

Habermas, J. (1998). Knowledge and human interests. Cambridge, UK: Polity Press. (Original work published 1972)

Joas, H. (1993a). Symbolic interactionism. In A. Giddens \& J. Turner (Eds.), Social theory today (pp. 82-115). Cambridge, UK: Polity Press.

Joas, H. (1993b). Pragmatism and social theory. Chicago: Chicago University Press.

Joas, H. (1996). The creativity of action. Cambridge, UK: Polity Press. (Original work published 1992)

Joas, H. (1997). G. H. Mead. A contemporary re-examination of his thought. Cambridge, MA: MIT Press. (Original work published 1980)

Jones, R. (1977). On understanding a sociological classic. American Journal of Sociology, 83, 279-319.

Jones, R. (1981). On Quentin Skinner. American Journal of Sociology, 87, 453-467.

Jones, R. (1983). On Merton's "history" and "systematics" of sociological theory. In Loren Graham et al. (Eds.), Functions and uses of disciplinary histories (Vol. 7; pp. 121-142). Dordrecht: Reidel Publishing Company.

Jones, R. (1984). Demythologizing Durkheim: A reply to Gerstein. Knowledge and Society, 5, 63-83.

Jones. R. (1986). Emile Durkheim. Beverly Hills, CA: Sage.

Jones, R. (1997). The other Durkheim: History and theory in the treatment of classical sociological thought. In C. Camic (Ed.), Reclaiming the sociological classics (pp. 142-172). London: Blackwell

Kuhn, T. (1962). The structure of scientific revolutions. Chicago: Chicago University Press.

Lepenies, W. (1988). Between literature and science: The rise of sociology. Cambridge, UK: Cambridge University Press.

Levine, D. (1995). Visions of the sociological tradition. Chicago: Chicago University Press.

Luhmann, N. (1979). Trust and power (T. Burns \& G. Poggi, Eds.). Chichester, UK: Wiley. (Original work published 1973)

MacIntyre, A. (1981). After virtue: A study in moral theory. Notre Dame, IN: Notre Dame Press.

MacIntyre, A. (1998). The relationship of philosophy to its past. In R. Rorty et al. (Eds.), Philosophy in history (pp. 31-48). Cambridge, UK: Cambridge University Press. (Original work published 1984)

Mead, G. H. (1912). The mechanism of social consciousness. Journal of Philosophy, Psychology, and Scientific Methods, 9, 401-406.

Mead, G. H. (1938). The philosophy of the act (C. Morris et al., Eds.). Chicago: University of Chicago Press.

Mead, G. H. (1972). Movements of thought of nineteenth century (M. H. Moore, Ed.). Chicago: Chicago University Press. (Original work published 1936)

Mead, G. H. (1997). Mind, self and society from the standpoint of a social behaviorist (C. Morris, Ed.). Chicago: Chicago University Press. (Original work published 1934)

Mead, G. H. (2002). The philosophy of the present (A. E. Murphy, Ed.). Amherst, NY: Prometheus Books. (Original work published 1932)

Merton, R. (1949). Social theory and social structure. Glencoe, IL: Free Press.

Merton, R. (1967). On the history and systematics of sociological theory. In R. Merton (Ed.), On theoretical sociology (pp. 1-37). New York: Free Press. (Original work published 1949)

Merton, R. (1975). Structural analysis in sociology. In P. Blau (Ed.), Approaches to the study of social structure (pp. 21-52). New York: Free Press.

Merton, R. (1980). On the oral transmission of knowledge. In R. Merton \& M. Riley (Eds.), Sociological traditions from generation to generation (pp. 1-35). Norwood, NJ: Ablex.

Mills, C. W. (1959). The social imagination. New York: Oxford University Press.

Parsons, T. (1968). The structure of the social action: A study in social theory with special reference to a group of recent European writers (Vol. 1). New York: The Free Press. (Original work published 1937)

Pocock, J. (1971). Politics, language and time. New York: Atheneum.

Pocock, J. (1985). Virtue, commerce, and history. Cambridge, UK: Cambridge University Press.

Poggi, G. (1996). Lego quia inutile: An alternative justification for the classics. In S. Turner (Ed.), Social theory and sociology. The classics and beyond (pp. 39-47). Oxford, UK: Blackwell Publishers.

Pope, W. (1973). Classic on classic: Parsons' interpretation of Durkheim. American Sociological Review, 38, $399-415$.

Rhea, B. (1981). Introduction. In B. Rhea (Ed.), The future of the sociological classics (pp. ix-xi). London: George Allen and Unwin.

Rorty, R. (1998). The historiography of philosophy: Four genres. In R. Rorty et al. (Eds.), Philosophy in history (pp. 49-75). Cambridge, UK: Cambridge University Press. (Original work published 1984)

Rorty, R. (2000). Intellectual historians and pragmatist philosophy. In J. Pettegrew (Ed.), A pragmatist's progress? Richard Rorty and American intellectual history (pp. 207-211). Lanham, UK: Rowman and Littlefield.

Skinner, Q. (1969). Meaning and understanding in the history of ideas. History and Theory, 8, 3-53.

Skinner, Q. (1970). Conventions and the understanding of speech acts. Philosophical Quarterly, 20, 118-138.

Skinner, Q. (1971). On performing and explaining linguistic actions. Philosophical Quarterly, 21, 1-21.

Skinner, Q. (1972). Motives, intentions and the interpretations of texts. New Literary History, 3, 398-408.

Skinner, Q. (1988). A reply to my critics. In J. Tully (Ed.), Meaning and context: Quentin Skinner and his critics (pp. 231-288). Cambridge, UK: Polity Press.

Stinchcombe, A. (1982). Should sociologists forget their fathers and mothers? American Sociologist, 17, 2-11. 
Stocking, G. (1965). On the limits of "presentism" and "historicism" in the historiography of the behavioral sciences. Journal of the History of the Behavioral Sciences, 1, 211-218.

Timasheff, N. (1955). Sociological theory: Its nature and growth. New York: Random House.

Tucker, C. (1988). Herbert Blumer: A pilgrimage with pragmatism. Symbolic Interaction, 11, 99-124.

Turner, S. (1983). "Contextualism" and the interpretation of the classic sociological texts. Knowledge and Society, 4, 273-291.

Woelfel, J. (1992). Comment on the Blumer-Bales dialogue concerning the interpretation of Mead's thought. In P. Hamilton (Ed.), George Herbert Mead: Critical assessments (Vol. 2; pp. 47-48). London: Routledge. (Original work published 1967) 